\title{
A Systematic Review on Search Engine Advertising
}

\author{
Hamed Jafarzadeh \\ Information Technology Services \\ University of Queensland, Brisbane, Australia \\ h.jafarzadeh@uq.edu.au \\ Aybüke Aurum \\ Aurum Academia, Sydney, Australia \\ aybuke.aurum@gmail.com \\ John D'Ambra \\ School of Information Systems \\ University of New South Wales, Sydney, Australia \\ j.dambra@unsw.edu.au \\ * Amir Ghapanchi \\ School of Information and Communication Technology \\ Griffith University, Gold Coast, Australia \\ a.ghapanchi@griffith.edu.au
}

\begin{abstract}
The innovation of Search Engine Advertising (SEA) was first introduced in 1998. It soon became a very popular tool among practitioners for promoting their websites on the Web and turned into a billion dollar revenue source for search engines. In parallel with its rapid growth in use, SEA attracted the attention of academic researchers resulting in a large number of publications on the topic of SEA. However, no comprehensive review of this accumulated body of knowledge is currently available. This shortcoming has motivated us to conduct a systematic review of SEA literature. Herewith, we searched for and collected 101 papers on the topic of SEA, published in 72 journals from different disciplines and analyzed them to answer the research questions for this study. We have identified the historical development of SEA literature, predominant journals in the publication of SEA research, active reference disciplines as well as the main researchers in the field of SEA. Moreover, we have classified SEA literature into four categories and 10 research topics. We also uncovered a number of gaps in SEA literature and provided future research direction accordingly.
\end{abstract}

Keywords: Search engine advertising, sponsored search, paid search, systematic literature review 


\section{Introduction}

Search engine advertising is paid for by businesses that are interested in displaying ads for their product/service/site alongside search engine results. Businesses bid for keywords, and their ad is displayed when the keyword is queried in the search engine (Fuxman et al., 2008). In recent years, Search Engine Advertising (SEA) has become an important and fast growing source of revenue for search engine companies as well as an effective method for businesses to promote themselves on the Web. Total industry revenue increased from approximately US $\$ 0.9$ billion in 2002 to about US $\$ 10$ billion in 2005 (Rashtchy et al., 2007) and exceeded US $\$ 37$ billion in 2009 (Quinn et al, 2012). It has been calculated that more than $90 \%$ of Google's annual revenue is derived from its sponsored search service which was reported as being around \$45 billion for 2014 (Google Quarterly Report, 2014).

Although SEA is attractive to advertisers, it is also a complex and dynamic form of advertising and managing it effectively is a difficult task. SEA is a multi-dimensional subject. Hence, SEA has attracted the attention of academic researchers not only from marketing, but also from information systems, computer science and mathematics. There is extensive research on the SEA domain, with topics ranging from mathematical and technical subjects (e.g., auction mechanisms, bidding strategy, information retrieval) to social and behavioral topics (e.g., attitude of web searchers toward sponsored links and perception of advertisers of its effectiveness). As a result, an extensive amount of academic literature on SEA has accumulated over the last decade.

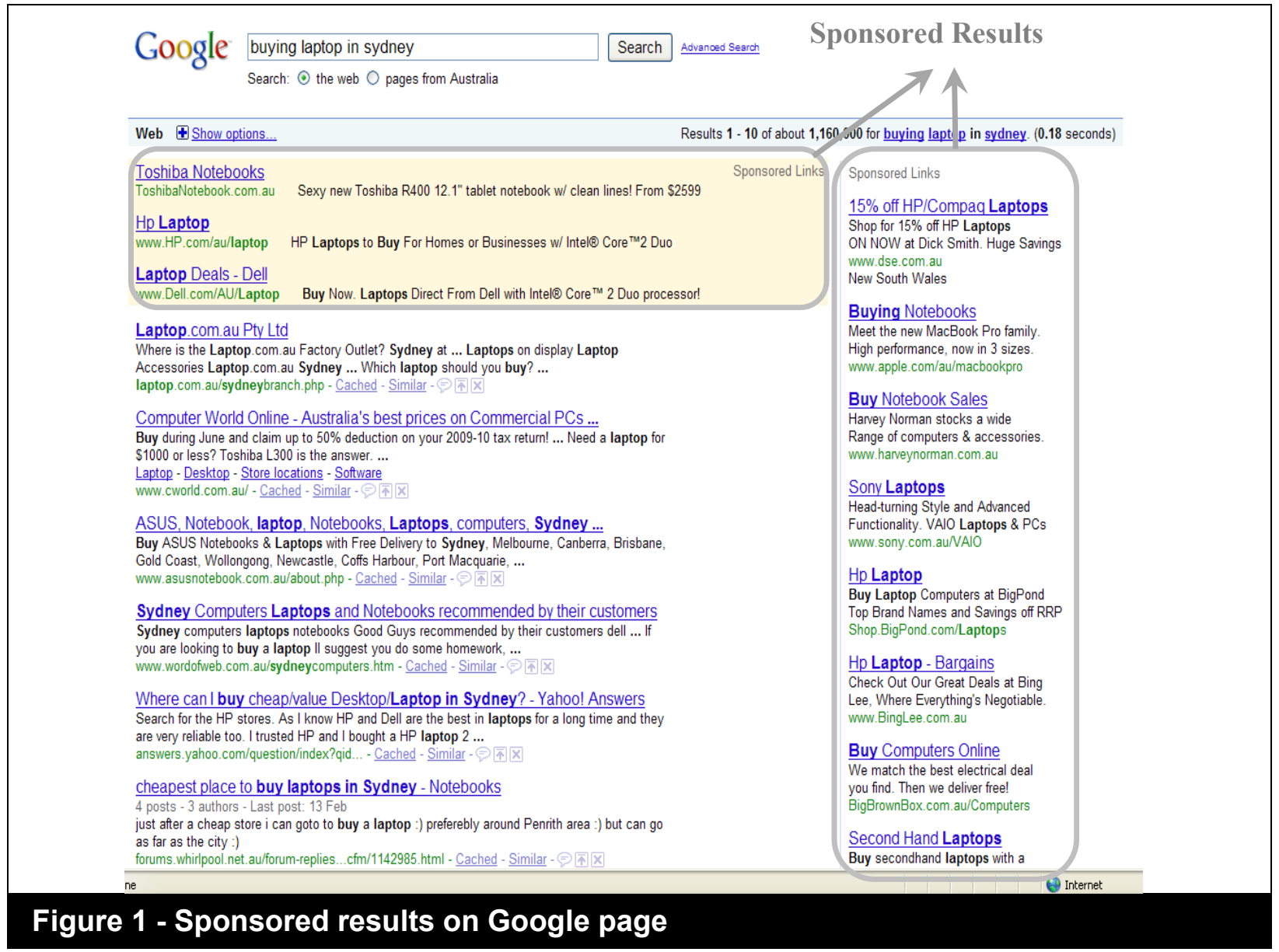

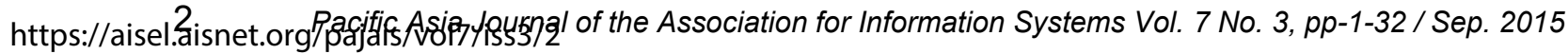


When an intensive body of literature becomes available in an area, it is important to organize and structure this literature in order to consolidate the knowledge in the area and provide directions for future research. Therefore, in most academic disciplines, researchers conduct literature reviews to understand underlying concepts and principles, summarize and organize the latest research results, and to provide a picture of the state of the art in their field (Staples and Niazi, 2007). To the best of our knowledge, a comprehensive systematic analysis of literature in the SEA domain has not yet been conducted. Although there has been a significant growth in the number of SEA studies and some prior researchers have raised the need for organizing literature on SEA (Barry and Charleton, 2009, Karjaluoto and Leinonen, 2009), there is currently a gap in the literature in terms of published studies devoted efforts toward organising SEA literature.

This paper is an attempt to overcome the above deficiency. This paper presents a systematic literature review on the SEA domain, provides a historical overview of the research literature on SEA, structures the existing body of knowledge on SEA and identifies areas for research in the future. We systematically searched for and collected 101 prior journal papers published in the domain of SEA and analyzed them to answer five research questions designed for this study. It is hoped that the output of this study could be of value to academic researchers. It could be helpful in creating a better understanding on the state of the art in SEA domain. The list of primary studies we identified in our literature survey can serve researchers as a comprehensive bibliography of prior journal publications on SEA. Also, the classification we created on SEA research categories and topics could be of value to researchers, as these classifications facilitate the retrieval of relevant research articles for researchers and provide a good starting point for literature survey.

\section{Search Engine Advertising}

Search engines today act as an information gateway to many information seeking and decision-making tasks. Given the critical role of search engines on Web users' actions and in transferring traffic to websites, many commercial organizations have realized the importance of gaining a high position on the search results page (Feng et al., 2007a). However, in reality, it is not easy for a business to obtain a high position on a search results page when thousands of websites are competing for the same thing (Karjaluoto and Leinonen, 2009). Search Engine Advertising (SEA) is one solution that has emerged to overcome this challenge (Feng et al., 2007a, Barry and Charleton, 2009, Karjaluoto and Leinonen, 2009). The innovation of SEA stems from the idea that, given the competitive environment for obtaining top positions in search engine rankings, it may be more effective to simply 'buy' such a position directly from search engines in order to gain visibility on the first page (Morochove, 2008, Sen, 2005).

In SEA (also called sponsored search and paid search advertising), search engines are paid by businesses that are interested in displaying ads (i.e., sponsored links) for their site alongside the search results. Businesses bid for keywords, and their ad is displayed when the keyword is queried on the search engine (Fuxman et al., 2008). In most cases, companies pay the search engine whenever a user clicks on the sponsored link. Sponsored results appear on the top, side and bottom of searchresults pages (Nicholson et al., 2006) (See Figure 1). 


\section{Research Design}

To ensure the quality of the results of any literature review, it is necessary to undertake a systematic approach (Kitchenham, 2004). Thus, we followed the systematic review guidelines proposed by Kitchenham (2004), Brereton (2007) and Staples and Niazi (2007) and conducted our review in six distinct stages explained in the following:

\section{Research questions}

According to review guidelines, one of the most important activities in conducting any systematic review is formulating the research questions (Kitchenham, 2004) since "the entire systematic review is driven by its research questions" (Staples and Niazi, 2007). The guidelines suggest that instead of having a general and broad research question, researchers should clearly and narrowly formulate specific research questions to clearly identify the scope of the review study and to control the effort and duration of the study. Therefore, according to these guidelines along with insights from similar studies studies in other fields (e.g., Karg et al., 2011, Glass et al., 2004) we postulate the following specific research questions for our study:

$R Q$ 1) How did research on the search engine advertising domain develop over time?

$R Q$ 2) What are the reference disciplines of search engine advertising publications?

$R Q$ 3) Which journals most frequently publish search engine advertising research?

$R Q$ 4) Who are the predominant researchers within the search engine advertising context?

$R Q$ 5) What are the research topics in the area of search engine advertising?

\section{Protocol development}

A pre-defined review protocol guides the whole research project and reduces the possibility of subjective bias imposed by researcher (Kitchenham, 2004). We established the protocol for our review study based on the procedure and guidelines offered by Kitchenham in her famous technical report at Keele University (see Kitchenham, 2004). The protocol explains the rationale for the research and the research questions (explained in previous sections), inclusion/exclusion criteria and quality assessment, strategy for collecting primary sources, data extraction strategy and the method for analyzing and synthesizing data.

\section{Inclusion/exclusion criteria and quality assessment}

Studies were required to satisfy several criteria to be eligible for inclusion in this research. First of all, they needed to be related to the search engine advertising context. A publication qualified for this criterion if it contained at least one section discussing search engine advertising or if it presented a finding about this topic.

Second, the publication must have been published in a peer-reviewed archival journal. We limited our study to journal papers because 1) including conference papers dramatically increased the number of primary sources which was difficult to manage, 2) more importantly, in most cases, the expanded and improved version of a good quality conference publication appears as a journal paper after a while, so it is reasonable to assume that the findings of quality conference papers are captured through journal publications. 3) Lastly, our decision to focus on journal papers is backed up by many other systematic review studies in which authors have excluded conference articles (Petter et al., 2008, Brereton et al., 2007).

The third criterion was the quality of the journal publishing the paper. To assess the quality of journals, we primarily used the ERA 2010 journal ranking released by the Australian Research Council1. This ranking categorizes journals as $A+, A, B, C$ and non-ranked. To avoid over-excluding

\footnotetext{
${ }^{1} \mathrm{http}: / / w w w . a r c . g o v-. a u /$ era/era_journal_list.htm
} 
sources, we included studies if they were ranked $\mathrm{C}$ or above. Moreover, to ensure that we did not exclude any quality work, we assessed the quality of the journals not listed in ERA using alternative ranking systems. In such cases, we assessed the quality of the journal by checking whether it was ranked $\mathrm{C}$ or above in ACPHIS 2 or CORE 3 rankings, or whether it was indexed by Journal Citation Reports (JCR)尺 4or by the Institute for Scientific Information (ISI)5 . Journals were only excluded if the

${ }^{2}$ Introduced by Australian Council of Professors and Heads of Information Systems:

http://www.acphis.org.au/index.php?option=content\&tas $\mathrm{k}=$ category\&sectionid $=6 \& \mathrm{id}=33 \&$ Itemid $=53$

${ }^{3}$ Introduces by Computing Research and Education

Association of Australasia

http://core.edu.au/index.php/categories/journals

${ }^{4} \mathrm{http}: / /$ admin-

apps.isiknowledge.com/JCR/JCR?PointOfEntry=Home\&SI

D=P2aLCdO2He1ohI@KFF@

${ }^{5} \mathrm{http}: / /$ science.thomsonreuters.com answer to all these quality questions was "No". We did not apply further quality criteria on the basis that the sources were journal publications and thus they would already have been subject to a peer review process (Brereton et al., 2007). Moreover, as SEA first appeared in 1998, we did not consider publications earlier than the 90s. Finally, all the papers not written in English were excluded.

\section{Primary studies selection process}

The term 'primary studies' refers to "individual studies contributing to the systematic review" (Kitchenham, 2004). To identify the relevant primary studies, we undertook a rigorous searching and screening process as depicted in Figure 2. The process involved three main steps: 1) data base search, 2) reference search (backward search), and 3) citation search (forward search).

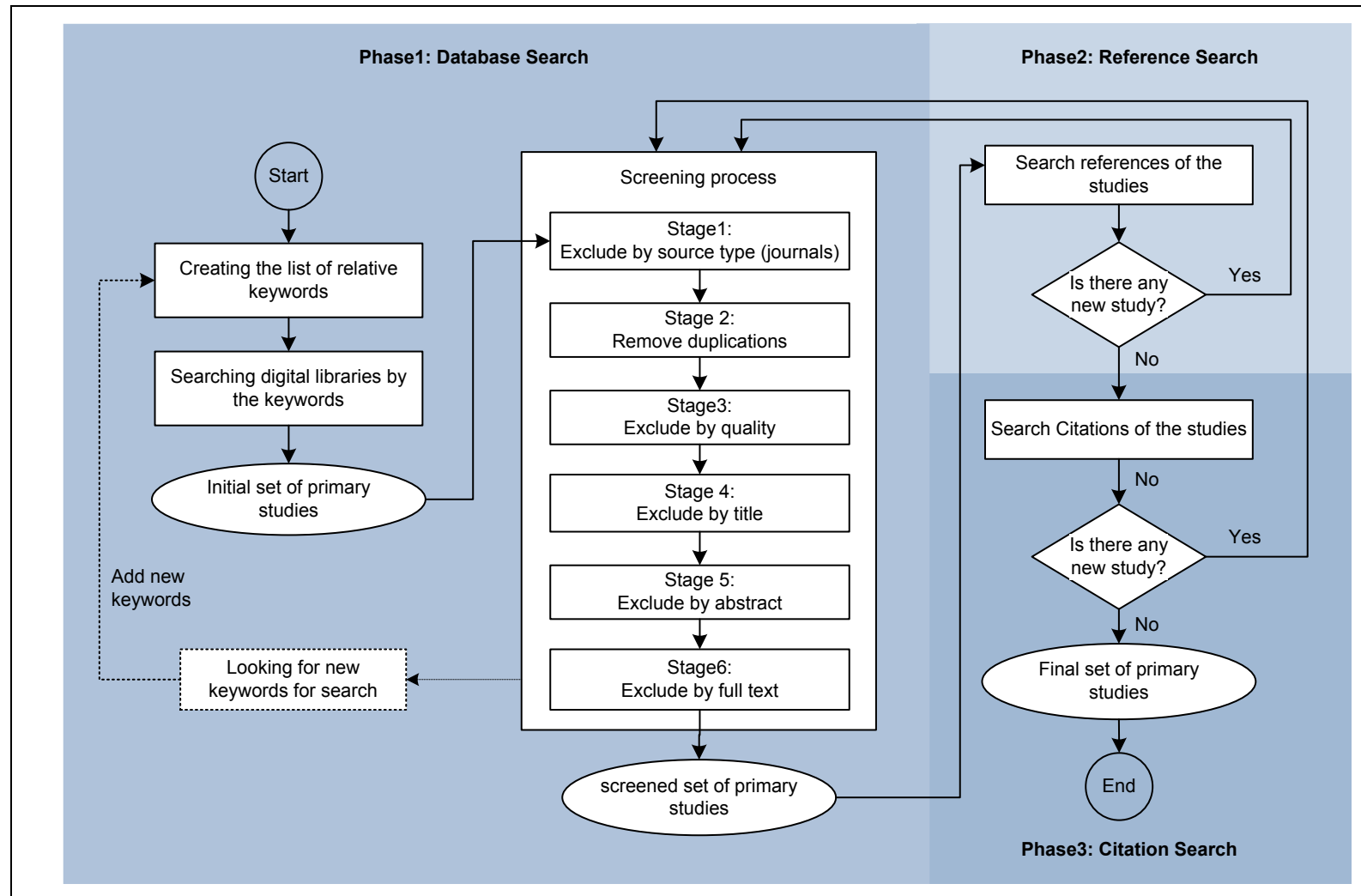

Figure 2 - The process for selecting primary studies 


\section{Step 1: Database search}

Phase 1 started with exploring the following digital resource databases:

Scopus, ScienceDirect, ISI Web of Science, Business Source Premier, Emerald, Inspec, ACM Digital Library, IEEE Xplore, Google Scholar (first 5 pages for each keyword), and InderScience.

The title, abstract, keywords, and in some cases the full text (depending on the search facilities of the databases) were searched. The SEA related search terms submitted to the databases included:

"sponsored search" OR "sponsored link" OR "sponsored links" OR "paid search" OR "sponsored list" OR "sponsored lists" OR "sponsored listing" OR "sponsored results" OR "sponsored result" OR "paid results" OR "paid links" OR "sponsored advertisement" OR "sponsored advertising" OR "sponsored advertisement" OR "pay per click" OR "pay per placement" OR "search engine marketing" OR "search engine advertisement" OR "search engine advertising" OR "Keyword advertising" OR "keyword ads search" OR "keyword auction" OR "paid placement" OR "search advertising" OR "contextual advertising".

The process of keyword identification and searching in academic data bases was a recursive process. That is, each time a new relevant keyword was recognized in a source paper, it was fed back to the search process for further exploring the databases.

As the result of this search strategy, we came up with a 2061 records as the initial set of primary studies (including duplications). Then, with the aid of Excel software, we started the screening process, which consisted of six distinct stages (see Figure 2). In Stage 1 of the screening process, we excluded those records that were not journals. 669 records remained after this stage. Then in stage 2, we removed duplications, old papers (before
1990) and those not in English, which resulted in 318 unduplicated journal publications.

In stage 3 papers were evaluated based on the quality assessment criteria explained in the previous section. Only those studies that passed the quality stage successfully (i.e., their journal rank was $C$ or above in one of the ranking systems, or that were indexed in JCR or ISI were retained. 290 papers satisfied this criterion and were used in the next stage.

In stage 4 , we reviewed the titles of all the publications to examine their relevance to our systematic review. We excluded those papers with titles that were not related to search engine advertising. In excluding these papers, we were aware that in some papers the title may not have been an accurate representation of the paper's content because authors tend to use witty titles which do not clearly reveal the real content of papers. So, we only excluded those papers where the irrelevancy of their title was quite clear and obvious. We otherwise retained papers for further analysis in the next stages. 91 papers were excluded at the title review stage.

In stage 5 , we read the abstracts of the remaining studies and judged the relevancy of these papers to our study in a similar way to stage 2. That is, if the abstract clearly showed that the paper was not about search engine advertising, the paper was excluded. In several cases, the abstract was poor, misleading or gave little insight about the full paper. In those cases the papers were included for further analysis in the next stage. The abstract screening stage resulted in the omission of a further 30 publications (169 remained after the conclusion of this stage).

To increase the credibility of the screening process and to minimize the possibility of leaving out relevant papers, stages 4 and 5 (i.e., exclusion by title and abstract) were carried out separately and individually by the three authors. First, the abstracts and the titles of the papers were entered into an 
Excel file, then each author went through the list and decided which papers should be included or excluded. Only those papers that were judged irrelevant by all three authors were excluded from the study. If at least one author considered that a paper was related to SEA, it was retained.

At the last stage of the screening process, the full text of the remaining 169 papers was examined. As discussed previously in the inclusion/exclusion section, the selection criterion for including papers was that they had at least one section talking about SEA or reported on a finding about this topic. 78 papers failed to satisfy this criterion and were consequently excluded. This left 91 papers which formed the screened set of primary studies to be included in the systematic review.

\section{Step 2: Reference search (backward search)}

Phase 2 contained three iterations. At this phase, we examined the 3228 references of the 91 papers in the screened set of primary studies to uncover new studies. We applied the same process to screen these reference papers. The screening process resulted in identifying 6 new publications which satisfied the inclusion criteria. Then we undertook a second iteration of searching the references of these 6 new papers $(n=224)$ in a similar process to iteration 1 , which resulted in 2 additional papers. The third iteration of searching references of these 2 papers did not return any new studies, and thus we stopped reference searching. In total, 8 additional publications were found in phase 2 .

\section{Step 3: Citation search (forward search)}

Although reference search (backward search) is a good method for finding related sources, it would be best if it is complimented by a citation search (forward search) (Ellis, 1989). Citation searching refers to "identifying citations to material consulted or known" (Ellis, 1989). It is a method that researchers can use to find more related literature by examining the later works which cited a particular article. To perform citation search, we examined all the papers that cited our primary studies. Searching via Scopus and Google Scholar, we found 154 papers cited our primary sources. Undertaking the same screening process on these 154 publications as we did in previous phases, we found 2 new related papers. These 2 papers had not received any citations, so no iterations were required and we finished our citation search. In total, our systematic review resulted in a final set of 101 primary studies related to search engine advertising $(91+6+2+2)$. Table 1 summarizes the number of papers excluded in each phase and stage.

\section{Data extraction and synthesis strategy}

To be able to analyze and aggregate the SEA literature, we first extracted the required data for answering our research questions based on the original terms used by the authors of each primary study. Then, with the aid of Excel, Access and EndNote software, we extracted and organized the data in a tabular format to enable us to compare and contrast and to translate the terms into a meaningful interpretation of data. The results were then discussed between the authors until agreement about the findings was reached. The results are presented and discussed in the following sections. 


\begin{tabular}{|lcc|}
\hline Table 1 - Number of papers included/excluded in each phase/stage & \\
\hline Phase/stage & \# of papers Excluded & $\begin{array}{c}\text { \# of papers } \\
\text { remained }\end{array}$ \\
\hline Step 1 & & 2601 (Initial set) \\
Stage 1 : Exclude non journals & 351 & 669 \\
Stage 2: Exclude duplications, old, non English & 28 & 318 \\
Stage 3: Exclude by quality & 91 & 290 \\
Stage 4: Excluded by title & 30 & 199 \\
Stage 5: Exclude by abstract & 78 & 169 \\
Stage 6: Exclude by full text & & 91 (Screened set) \\
\hline Step 2 & 3222 & 3228 \\
Iteration 1 & 222 & 6 \\
Iteration 2 & & 2 \\
\hline Step 3 & 152 & 154 \\
Iteration 1 & & 2 \\
\hline Total & & $91+6+2+2=101$ (Final set) \\
\hline
\end{tabular}

\section{Results}

In this section we answer and discuss the research questions according to the results from our analysis of the primary studies.

\section{Temporal development of literature (RQ1)}

Table 2 and Figure 3 show the number and the trend of SEA publications over time. According to the results of our search process, the first journal publication appeared in 2003 and there has since been rapid growth in the number of publications.
In each year, the number of published papers was found to be higher than (or at least equal to) the number of publications in the previous year, and no decline in the trend was observed (It should be noted that the information for 2011 covered only the first two months of the year). This historical trend was predictable because, although SEA first introduced in 1998 by Overture (Jansen and Spink, 2007), a major expansion in the field of SEA took place in 2004 when Google stepped into this industry (Rashtchy et al., 2007). Accordingly, the research on SEA intensified after 2004.
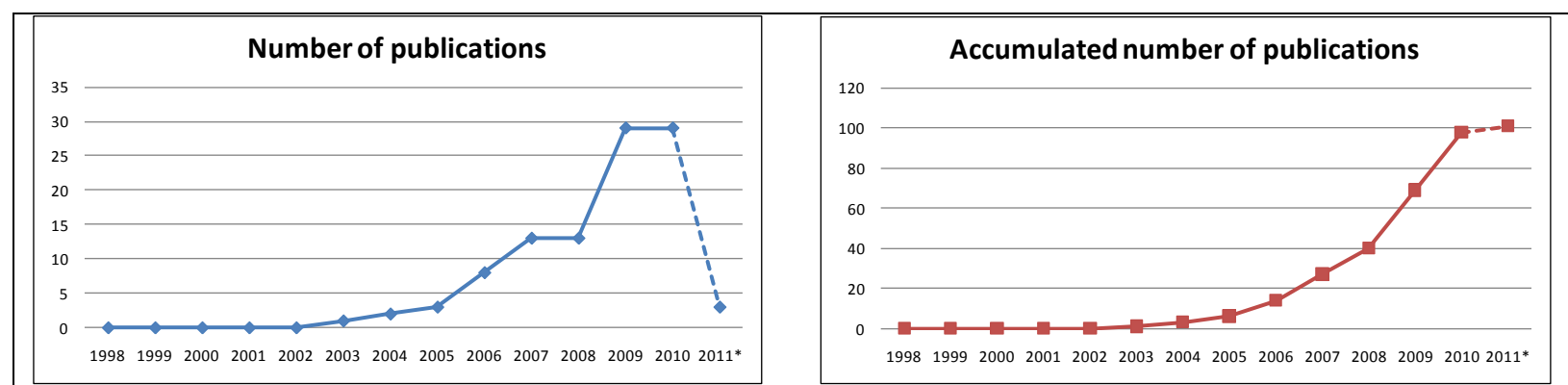

Figure 3 - Temporal development of SEA literature 


\begin{tabular}{|c|c|}
\hline Table 2 - Number of publications per year & \\
\hline Year & Number of publications \\
\hline 2003 & 1 \\
\hline 2004 & 2 \\
\hline 2005 & 3 \\
\hline 2006 & 8 \\
\hline 2007 & 13 \\
\hline 2008 & 13 \\
\hline 2009 & 29 \\
\hline 2010 & 29 \\
\hline $2011^{*}$ & 3 \\
\hline
\end{tabular}

\section{Reference disciplines of SEA research (RQ2)}

In many research domains, researchers have investigated how publications in their fields are distributed across different disciplines (e.g., Glass et al., 2004, Karg et al., 2011). This is helpful in providing a better understanding of the origins of the literature. It is especially more important in the field of SEA as it is multidimensional and offers interesting topics for researchers from various disciplines, including marketing, information systems, computer science, mathematics and so on.

To categorize SEA literature based on the research disciplines, we used the classifications offered by the Australian Research Council in which a primary field is assigned to each journal. Applying this classification, we realized that our set of 101 primary studies originated from 25 disciplines (Table 3, primary disciplines column). We observed some similarities between these 25 disciplines, so we decided to group these disciplines into some broad and distinct groups to enable us to provide a more sensible classification for the origins of the publications. To do this, the first author initially classified the 25 disciplines into groups and the results of this grouping were discussed between all the authors until agreement was reached on the groupings. This process resulted in the classification of the 25 primary disciplines into seven groups: information systems; marketing and business; mathematic and computing; economics; law; heath care and other. Although we did our best to propose reasonable classifications, we acknowledge their subjectivity.

Based on our data, the most active discipline in SEA research was information systems which covered more than one third of the literature. This finding is interesting as it emphasizes the importance of Information Technology (IT) in sponsored search industry. While technology plays a limited role in traditional marketing, in the online world, technology is a crucial component of digital marketing (Rashtchy et al., 2007). Particularly in search engine advertising, IT is a critical and inseparable part of the industry and the whole of SEA is enabled by IT. Consequently it is not surprising that a significant body of SEA knowledge has been developed in the IT/IS discipline.

Disciplines related to computation and mathematics had also devoted efforts towards SEA research and $17.8 \%$ of the literature was developed by these disciplines. Papers published in these disciplines tended to investigate the complex algorithmic and computational mechanisms for running search engine advertising and displaying and sorting sponsored results. In addition, economic 
aspects of SEA, such as revenue models for both search engine companies and advertisers, have made SEA an interesting research topic for economists. Also, SEA is affected by regulatory issues which has brought Law academics into SEA research.
Finally, some other disciplines, such as health care, education and journalism, have developed interest in SEA mainly to examine the outcomes of employing sponsored links in their respective fields.

\begin{tabular}{|c|c|c|c|c|}
\hline $\begin{array}{l}\text { Reference } \\
\text { disciplines } \\
\text { (grouped) }\end{array}$ & Primary reference discipline & $\begin{array}{l}\text { Number of } \\
\text { publications }\end{array}$ & $\begin{array}{l}\text { Number of } \\
\text { publications }\end{array}$ & percentage \\
\hline \multirow{2}{*}{$\begin{array}{l}\text { Information } \\
\text { Systems }\end{array}$} & Information Systems & 26 & \multirow{2}{*}{36} & \multirow{2}{*}{$35.6 \%$} \\
\hline & Library and Information Studies & 10 & & \\
\hline \multirow{4}{*}{$\begin{array}{l}\text { Marketing } \\
\text { and } \\
\text { business }\end{array}$} & Marketing & 12 & \multirow{4}{*}{28} & \multirow{4}{*}{$27.7 \%$} \\
\hline & Business and Management & 11 & & \\
\hline & Commercial Services & 3 & & \\
\hline & $\begin{array}{l}\text { Commerce, Management, Tourism } \\
\text { and Services }\end{array}$ & 2 & & \\
\hline \multirow{9}{*}{$\begin{array}{l}\text { Mathematics } \\
\text { and } \\
\text { Computing }\end{array}$} & Information and Computing Sciences & 6 & \multirow{9}{*}{18} & \multirow{9}{*}{$17.8 \%$} \\
\hline & Distributed Computing & 3 & & \\
\hline & $\begin{array}{l}\text { Computation Theory and } \\
\text { Mathematics }\end{array}$ & 2 & & \\
\hline & $\begin{array}{l}\text { Artificial Intelligence and Image } \\
\text { Processing }\end{array}$ & 1 & & \\
\hline & Applied Mathematics & 1 & & \\
\hline & Data Format & 1 & & \\
\hline & Mathematical Sciences & 2 & & \\
\hline & $\begin{array}{l}\text { Numerical and Computational } \\
\text { Mathematics }\end{array}$ & 1 & & \\
\hline & $\begin{array}{l}\text { Other Information and Computing } \\
\text { Sciences }\end{array}$ & 1 & & \\
\hline Law & Law & 8 & 8 & $7.9 \%$ \\
\hline \multirow{3}{*}{ Economics } & Economics & 2 & \multirow{3}{*}{4} & \multirow{3}{*}{$4.0 \%$} \\
\hline & Applied Economics & 1 & & \\
\hline & Economic Theory & 1 & & \\
\hline \multirow{2}{*}{ Health care } & Public Health and Health Services & 2 & \multirow{2}{*}{3} & \multirow{2}{*}{$3.0 \%$} \\
\hline & Medical and Health Sciences & 1 & & \\
\hline \multirow{4}{*}{ Other } & Electrical and Electronic Engineering & 1 & \multirow{4}{*}{4} & \multirow{4}{*}{$4.0 \%$} \\
\hline & Journalism and Professional Writing & 1 & & \\
\hline & Mechanical Engineering & 1 & & \\
\hline & Education Systems & 1 & & \\
\hline
\end{tabular}

\section{Related Journals (RQ3)}

According to our data, research on SEA was published across 72 journals (see Table 4). International Journal of Electronic Commerce had most frequently published search engine advertising research by publishing six articles. It was followed by Information Systems Research $(n=5)$, and then by Electronic Commerce Research and Applications and International Journal of
Internet Marketing and Advertising (4 articles in each). Among all the journals, 15 journals published at least 2 papers. In total, 44 papers were published in such journals. The remaining 57 papers appeared in journals with only one publication in the SEA domain. The list of these 57 journals is presented in Appendix A.

Our data indicates that even though some journals had published SEA articles more 
than the others, there was no outstanding dominant journal in the publication of SEA studies. Literature in this area is dispersed over a wide range of journals. A possible explanation for such a distribution may be that, as discussed previously, SEA is a multidimensional topic and thus a wide spectrum of journals are appropriate to publish research in this area. We also found there was no specific journal specializing in search engine advertising.

\section{Table 4 - Distribution of SEA research across journals}

\begin{tabular}{|l|c|c|l|}
\hline Journal & \# of publications & Rank & Reference discipline \\
\hline $\begin{array}{l}\text { International Journal of Electronic } \\
\text { Commerce }\end{array}$ & 6 & A & Information Systems \\
\hline Information Systems Research & 5 & A $^{*}$ & Information Systems \\
\hline $\begin{array}{l}\text { Electronic Commerce Research and } \\
\text { Applications }\end{array}$ & 4 & C & Information Systems \\
\hline $\begin{array}{l}\text { International Journal of Internet } \\
\text { Marketing and Advertising }\end{array}$ & 4 & C & Marketing \\
\hline Decision Support Systems & 3 & A $^{*}$ & $\begin{array}{l}\text { Information and Computing } \\
\text { Sciences }\end{array}$ \\
\hline $\begin{array}{l}\text { International Journal of Electronic } \\
\text { Business }\end{array}$ & 3 & C & Business and Management \\
\hline $\begin{array}{l}\text { Journal of the American Society for } \\
\text { Information Science and Technology }\end{array}$ & 3 & A $^{*}$ & Library and Information Studies \\
\hline Computer Law and Security Report & 2 & B & Law \\
\hline American Economic Review & 2 & $A^{*}$ & Economics \\
\hline $\begin{array}{l}\text { Information Processing and } \\
\text { Management }\end{array}$ & 2 & A & Information Systems \\
\hline Marketing Science & 2 & $A^{*}$ & Marketing \\
\hline Computer & 2 & B & $\begin{array}{l}\text { Information and Computing } \\
\text { Sciences }\end{array}$ \\
\hline Journal of Interactive Advertising & B & Marketing \\
\hline $\begin{array}{l}\text { Production and Operations } \\
\text { Management }\end{array}$ & 2 & B & Business and Management \\
\hline Electronic Markets & A & Library and Information Studies \\
\hline Other journals with one article & A & NA \\
\hline
\end{tabular}

Another noteworthy point is the rank of the journals that published the SEA articles. Nowadays, academics are encouraged to publish in highly ranked journals, therefore Table 4 is useful as it can serve as a guideline for the journals in which SEA researchers should publish their findings. In general, about half of the papers were published in $A^{*}$ and $A$ ranked journals. The distribution of publications based on Journal ranking is presented in Table 5 . In general, the number of papers in each ranking category was similar.

\section{Table 5 - Distribution of SEA research across journals}

\begin{tabular}{|c|c|c|}
\hline Journal rank & Number of publications & percentage \\
\hline$A^{*}$ & 26 & $26 \%$ \\
\hline A & 27 & $27 \%$ \\
\hline B & 23 & $23 \%$ \\
\hline C & 25 & $25 \%$ \\
\hline
\end{tabular}




\section{SEA researchers (RQ4)}

According to our data, a total of 176 authors published journal papers in the SEA domain. 24 of these authors had been involved in at least two papers as either the author or coauthor. They are listed in Table 6. Among these 24 authors, eleven published more than three papers. The other 152 authors had only produced one paper. Those 24 authors with more than one paper had contributed to 37 of the 101 primary studies, which accounted for 36.6 percent of the overall literature. Therefore, is it fair to say that their contribution to SEA knowledge is quite substantial.
As can be seen in Table 6 , Jansen is the predominant researcher in the field of search engine advertising. He is the author of 12 papers of which he is the first author in 9. Based on our data, Professor Jansen and his coworkers, at The Pennsylvania State University, have contributed to $11.8 \%$ of academic knowledge in the SEA domain which is quite significant. They are mostly interested in studying the behavior of web searchers toward sponsored links and in finding solutions for improving click-through rates on sponsored links. We also found that most of the top 24 researchers had published their works in collaboration with others and only three authors (i.e. Jansen, Laffey and Gauzente) had published solitary.

\begin{tabular}{|c|c|c|c|c|c|c|c|c|c|}
\hline Author & \# of papers & $\begin{array}{l}\text { First } \\
\text { author }\end{array}$ & $\begin{array}{l}\text { Second } \\
\text { author }\end{array}$ & $\begin{array}{l}\text { Sole } \\
\text { Author }\end{array}$ & Author & $\begin{array}{c}\text { \# of } \\
\text { papers }\end{array}$ & $\begin{array}{l}\text { First } \\
\text { author }\end{array}$ & $\begin{array}{l}\text { Second } \\
\text { author }\end{array}$ & $\begin{array}{l}\text { Sole } \\
\text { Author }\end{array}$ \\
\hline Jansen, B. J. & 12 & 9 & 3 & 2 & Narahari, Y. & 2 & 0 & 2 & 0 \\
\hline Chen, J. & 5 & 2 & 2 & 0 & Saberi, A. & 2 & 0 & 1 & 0 \\
\hline Edelman, B. & 5 & 5 & 0 & 0 & Gauzente, C. & 2 & 2 & 0 & 2 \\
\hline Whinston, A.B. & 3 & 0 & 0 & 0 & Shen, Z.-J. M. & 2 & 1 & 1 & 0 \\
\hline Spink, A. & 3 & 1 & 1 & 0 & Ma, Z. & 2 & 1 & 0 & 0 \\
\hline Feng, J. & 3 & 2 & 1 & 0 & Schwarz, M. & 2 & 0 & 1 & 0 \\
\hline Ghose, A. & 3 & 1 & 2 & 0 & Resnick, M. & 2 & 0 & 1 & 0 \\
\hline Bu, T.-M. & 3 & 3 & 0 & 0 & Deng, X. & 2 & 0 & 2 & 0 \\
\hline Liu, D. & 3 & 2 & 1 & 0 & Ostrovsky, M. & 2 & 0 & 2 & 0 \\
\hline Qi, Q. & 3 & 0 & 0 & 0 & Yang, S. & 2 & 1 & 1 & 0 \\
\hline Laffey, D. & 3 & 3 & 0 & 1 & Mahdian, M. & 2 & 1 & 1 & 0 \\
\hline Asdemir, $\mathrm{K}$. & 2 & 2 & 0 & 0 & Sharp, J.A. & 2 & 0 & 1 & 0 \\
\hline
\end{tabular}

\section{Research categories and topics (RQ5)}

To classify SEA literature based on the topic of the studies, we analyzed our primary sources using an analysis process analogous to the method used in qualitative data analysis (Neuman, 2006). We first extracted the research topic of each primary study using the original terms used by the authors. Then we organized the extracted data in a tabular format to enable us to compare and contrast the research topics of the primary studies to understand the commonalities and differences across them and to translate the findings into higherorder interpretation of research topics. The results were then discussed between the authors until agreement about the categories for SEA research topics was reached and the corresponding category for each primary study was identified.

Our data extracting and synthesizing strategy revealed that the research on SEA could be classified into four broad categories of research: 1) research about the SEA mechanism, 2) behavioral and applied research, 3) research on legal aspects, and 4) overview research. These categories are discussed in the following sections. The list of studies belonging to each category is presented in Appendix B. 


\section{Research about the SEA mechanism}

The technology underlying sponsoredsearch platforms-including online auctions, geotargeting, and keyword volume prediction-is extremely complex (Jansen et al., 2009a). Therefore, a large amount of research on SEA is concerned with issues related to the technical aspects of the SEA mechanism. Most of the researchers who have papers in this category have a mathematical and computational perspective and are interested in mathematical, algorithmic and gametheoretic questions related to SEA (Karlin, 2007). They concentrate, for example, on designing, evaluating and validating various auction mechanisms (such as generalized second-price (GSP) auctioning or VickreyClarke-Groves (VCG) auctioneering) (e.g., Huang and Kauffman, 2010), proposing models for optimal and near-optimal bidding strategy (e.g., Chaitanya and Narahari, 2010), game-theory equilibrium analysis (e.g., Edelman and Schwarz, 2010), developing new mathematical models for optimizing the revenue of search engines (e.g., Garg and Narahari, 2009), algorithms for budget allocation (e.g., Chen and Li, 2009), proposing semantic techniques for keyword generation (e.g., Chen, 2010) and so on. Evaluating our primary sources, we found that $36.6 \%$ of the SEA literature fell into this category $(n=37)$.

\section{Behavioral and practical research}

There are also those studies that do not report on the technical aspects of the SEA mechanism. Instead, they investigate the behavioral, applied or business-related aspects of this technology. One group of such studies focuses on the behavior of SEA stakeholders (i.e., search engine users and advertisers). They pose questions such as: What is the web searcher's attitude and behavior toward sponsored links (e.g., Gauzente, 2009)? How do they perceive the presence of such advertising (e.g., Jansen and Spink, 2007)? How likely it is for a web user to click on a sponsored link (e.g., Jansen et al., 2007)? What is the perception of advertising businesses of SEA effectiveness (e.g., Karjaluoto and Leinonen, 2009)? and, practical suggestions for advertisers to best employ SEA (e.g., Laffey, 2007).

Another group of works in this category considers actual and structural questions about the emergence of sponsored links on search engine result pages, such as the number and proportion of sponsored links and the interrelationships between organic and sponsored results (e.g., Nicholson et al., 2006). Other research investigates the practical outcomes and achievements of employing a sponsored search advertising strategy in the real market in different industries - for example tourism (e.g., O'Connor, 2009) or healthcare (e.g., Walji et al., 2005). This category was the largest category in terms of the number of papers and accommodates about half of the prior literature $(n=51)$.

\section{Research on Legal aspects}

The research in this category, which was mostly published in law journals, concerns the regulatory issues of the search engine advertising industry. For example, these articles discussed the litigation undertaken by some businesses against search engine companies regarding the practice of recommending and selling their registered trademarks as a keyword (e.g., Malkawi, 2010). These papers also examined the approach of courts in different countries in regard to the practice of search engine advertising according to the local trade mark laws of each country (e.g., Tay, 2009). We found eight papers which investigated the regulatory aspects of SEA phenomenon.

\section{Overview research}

Publications in this category concerned the definition and review of the purpose, scope, and components of the search engine advertising industry (e.g., Jansen and Mullen, 2008, Ashley et al., 2008). Although there were few papers in this category that provided discussion of prior works (e.g., Zeng et al., 2008), none could be described 
as (systematic) literature review papers. Five papers in our primary study set belonged to this category.

According to the above categories, we propose Figure 4 as articulating the classifications for current available literature on search engine advertising based on the broad research topic. Also, Table 7 shows the number and percentage of the primary studies.

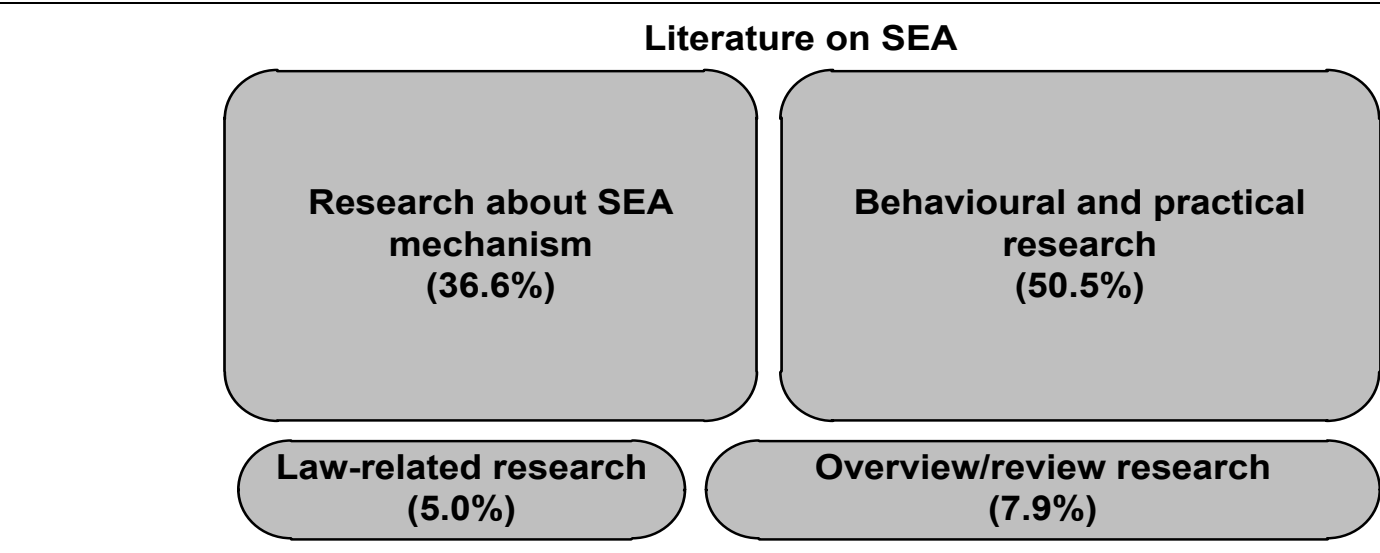

Figure 4 - Preliminary classification on SEA literature

\begin{tabular}{|lcl|}
\hline \multicolumn{4}{|l|}{ Table $\mathbf{7}$ - Number and percentage of the primary studies for each category } \\
\hline Category & $\#$ & $\%$ \\
\hline Research about SEA mechanism & 37 & $36.6 \%$ \\
Behavioral and practical research & 51 & $50.5 \%$ \\
Research on legal aspects & 5 & $5.0 \%$ \\
Overview/review research & 8 & $7.9 \%$ \\
Total & 101 & $100 \%$ \\
\hline
\end{tabular}

Moreover, to further classify the prior research, especially in the first two categories which accommodate a significant body of the literature, we again analyzed the research in each category using a similar approach analogous to the qualitative data analysis. We first extract the research topic in original terms, organized them in tabular format to reveal commonalities and differences, and then extensively discussed among researchers until an agreement on the topics classification was achieved. We also used some inputs from Zeng et al. (2008) in framing some of the topics. Ultimately, our analysis revealed that the previous research in the area of SEA can be classified into 10 research topics as introduced in Table 8. 


\section{Table 8 - Classification of SEA literature based on research topics}

\begin{tabular}{|c|c|c|c|}
\hline Research topic & Description & Examples & $\begin{array}{c}\text { Total } \\
\text { number }\end{array}$ \\
\hline Auction mechanism design & $\begin{array}{l}\text { SEA works according to an auction mechanism in which the advertisers bid on } \\
\text { keywords to get the highest position on the sponsored section of the result page, The } \\
\text { importance and complexity of SEA auction mechanism has attracted the attention of the } \\
\text { research community and several studies have focused on the design, evaluation and } \\
\text { validation of various auction mechanisms. Most of these studies had mathematical and } \\
\text { computational perspectives and were interested in algorithmic and game-theoretic } \\
\text { questions related to the auction mechanism issues. the objective of the studies in this } \\
\text { group was to find innovative ways for improving SEA auction mechanisms in order to } \\
\text { optimize the revenue of search engines }\end{array}$ & $\begin{array}{l}\text { Garg and Narahari, } \\
(2009), \text { Edelman et } \\
\text { al., (2007), Yoon, } \\
(2010) \text {. }\end{array}$ & 19 \\
\hline Bidding strategy optimization & $\begin{array}{l}\text { As sponsored search technology works on the basis of auctioning, advertisers need to } \\
\text { bid on a set of selected keywords. In this situation, one of the key challenges faced by } \\
\text { advertisers is determining the optimal bids for the selected keywords to maximize the } \\
\text { profit out of the advertising costs. This challenge has motivated researchers to carry out } \\
\text { studies with the objective of proposing optimal and near-optimal bidding strategy to } \\
\text { advertisers. These researchers have offered their strategies regarding different } \\
\text { properties, characteristics and problems that exist in sponsored search context. }\end{array}$ & $\begin{array}{l}\text { Chaitanya and } \\
\text { Narahari (2010), } \\
\text { Gluhovsky (2010), } \\
\text { Dhar and Ghose } \\
\text { (2010), Hillard } \\
\text { (2011) }\end{array}$ & 12 \\
\hline Keyword selection & $\begin{array}{l}\text { Selecting right and most effective keywords to bid on is critical in SEA process. } \\
\text { Researchers have studied this issue from different aspects such as analyzing the } \\
\text { importance of the using long tail keywords (less popular keywords employed by web } \\
\text { searchers, exploring the phenomenon of piggybacking (bidding on the brand name of } \\
\text { competitors to be listed on the result page), proposing integrated keyword suggestion } \\
\text { system to improve the performance of advertisers, and so on. }\end{array}$ & $\begin{array}{l}\text { Rutz and Buclin } \\
\text { (2011), Skiera et al. } \\
(2010), \text { Chen } \\
(2010)\end{array}$ & 6 \\
\hline SERP analysis & $\begin{array}{l}\text { A number of previous studies have considered answering structural questions about the } \\
\text { emergence of sponsored links on search engine result pages (SERPs), such as } \\
\text { whether the presence of organic listings on search engines is associated with a } \\
\text { positive, negative, or neutral effect on the click-through rates of sponsored search } \\
\text { advertisements and vice versa, or examining the overlap between organic and } \\
\text { sponsored search results retrieved by different major search engines. }\end{array}$ & $\begin{array}{l}\text { Yang and Ghose } \\
(2010), \text { Höchstötter } \\
\text { and Lewandowski } \\
(2009) \text {, Spink et al. } \\
(2006)\end{array}$ & 4 \\
\hline Click fraud issues & $\begin{array}{l}\text { The phenomenon of click fraud, defined as a type of internet crime that occurs when a } \\
\text { person, an automated script, or any computer program imitates a legitimate user of a } \\
\text { web browser and clicks on the links solely to make advertisers pay, has attracted the } \\
\text { attention of researchers from both technical and behavioural perspectives. }\end{array}$ & $\begin{array}{l}\text { Kshetri (2010), } \\
\text { Midha (2009), Dinev } \\
\text { et al. (2009), }\end{array}$ & 4 \\
\hline $\begin{array}{l}\text { Web searchers' behaviour and } \\
\text { practice }\end{array}$ & $\begin{array}{l}\text { The long term viability of sponsored search business model ultimately depends on how } \\
\text { web searchers interact with sponsored links. If search engine users find sponsored } \\
\text { contents useful in satisfying their information needs, they might click on sponsored links } \\
\text { (and consequently there would be revenue for search engines). Otherwise, users simply }\end{array}$ & $\begin{array}{l}\text { Gauzente (2009), } \\
\text { Jansen and Spink } \\
\text { (2007), Gauzente, } \\
(2010)\end{array}$ & 18 \\
\hline
\end{tabular}


Pacific Asia Journal of the Association for Information Systems, Vol. 7, Iss. 3 [2015], Art. 2

A Systematic Review on Search Engine Advertising / Jafarzadeh et al.

\begin{tabular}{|c|c|c|c|}
\hline & $\begin{array}{l}\text { ignore these links. Therefore, the billion dollar turnover of sponsored search industry is } \\
\text { at stake depending on behaviors and actions of users toward sponsored links. The } \\
\text { importance of this issue has motivated researchers to investigate the interaction of web } \\
\text { searchers with sponsored links. }\end{array}$ & & \\
\hline $\begin{array}{l}\text { Advertisers' behaviour and } \\
\text { practice }\end{array}$ & $\begin{array}{l}\text { Several studies have focused on business aspects of SEA phenomenon from } \\
\text { advertisers' perspective, such as exploring the perception of businesses towards } \\
\text { sponsored search advertising and their thoughts about its benefits and challenges, } \\
\text { provided suggestions, tips, and recommendations to business managers regarding how } \\
\text { to employ SEA more effectively, and so on. }\end{array}$ & $\begin{array}{l}\text { Karjaluoto and } \\
\text { Leinonen (2009), } \\
\text { Heinonen and } \\
\text { Michelsson (2010), } \\
\text { Paraskevas et al. } \\
\text { (2011) }\end{array}$ & 10 \\
\hline Real outcomes of SEA & $\begin{array}{l}\text { Another group of researchers had tried to understand the actual results and outcomes } \\
\text { of using SEA in the real market. They explored this topic from different angles such as } \\
\text { investigating whether SEA has enabled companies to attract more traffic to their } \\
\text { websites, exploring the capability of SEA in reaching to those customers that are not } \\
\text { accessible via other alternative advertising medium, etc. }\end{array}$ & $\begin{array}{l}\text { McAnulty (2009), } \\
\text { Estrada et al. } \\
\text { ( 2011), Goldfarb } \\
\text { and Tucker (2008, } \\
\text { 2011) }\end{array}$ & 15 \\
\hline Reviews on SEA & $\begin{array}{l}\text { Publications in this category were concerned with reviewing and discussing different } \\
\text { elements of SEA industry such as its history, purpose, scope, components, and risks. } \\
\text { There were few papers in this category that discussed prior SEA research, but none of } \\
\text { them was a literature review. }\end{array}$ & $\begin{array}{l}\text { Zeng et al. (2008), } \\
\text { Jansen and Mullen } \\
\text { (2008), Mowshowitz } \\
\text { and Kumar (2009) }\end{array}$ & 8 \\
\hline Legal aspects of SEA & $\begin{array}{l}\text { The research in this category, which was mostly published in law journals, concerns the } \\
\text { regulatory issues of the search engine advertising industry. }\end{array}$ & $\begin{array}{l}\text { Kemnitzer (2010), } \\
\text { Malkawi (2010), } \\
\text { Polanski (2011) }\end{array}$ & 5 \\
\hline
\end{tabular}


Aiming to provide a visual illustration of the existing body of SEA literature, we created Figure 5 as a graphical representation of the research categories and topics in SEA domain. In this Figure, each research topic is presented by a horizontal bar. The size of the bar represents the amount of previous literatures that fell into that research topic.
Also, the research topics are located within the four previously recognized research categories. The click fraud group sits on the border of the first two categories as we realized that the identified research in this group have the mixture of behavioural/practical and technical/mathematical nature.

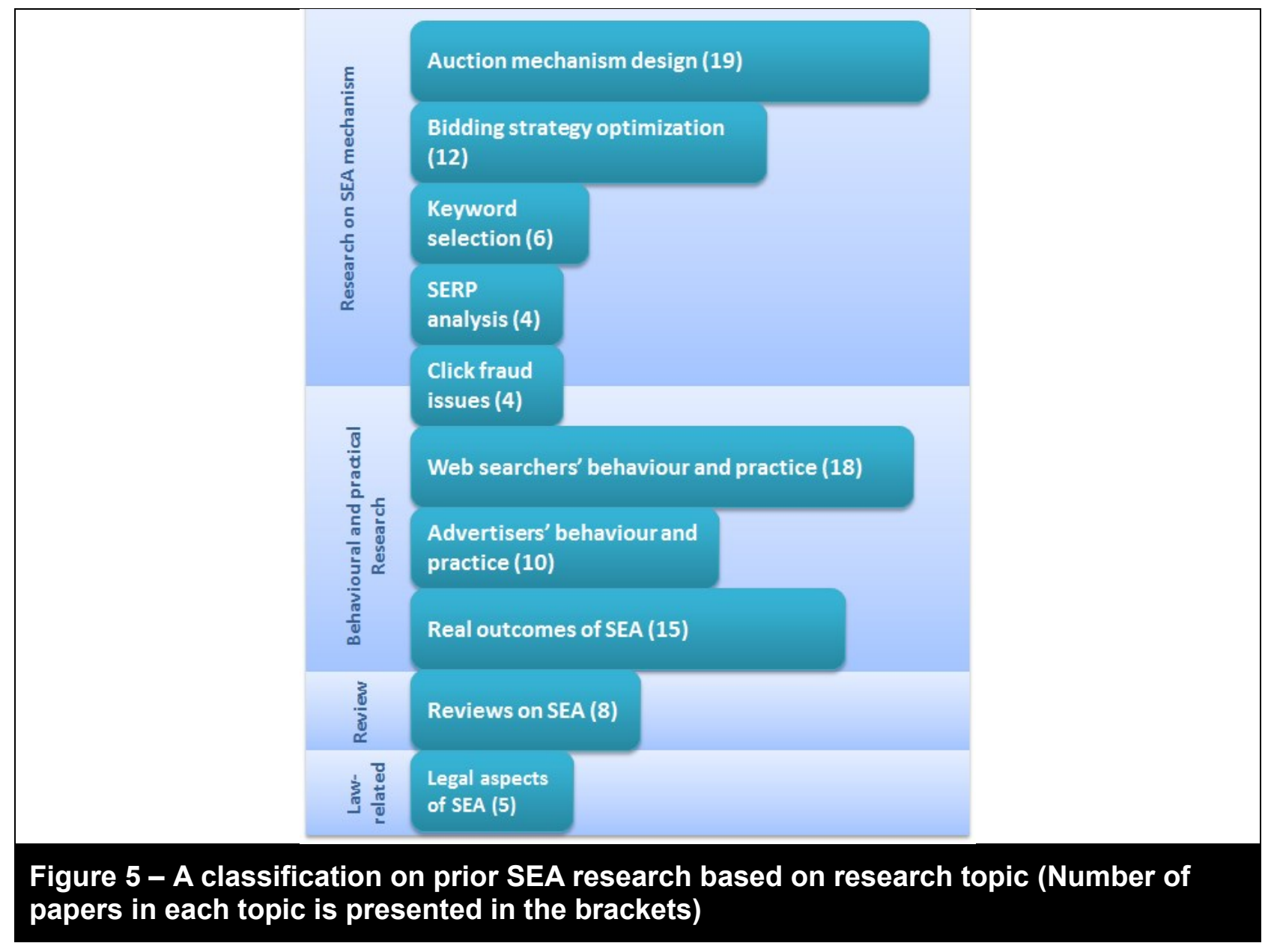

\section{Discussion}

Information Technology (IT) has made significant impact on our lives (Amrollahi et al., 2013, Ghapanchi and Aurum, 2012, Zarei and Ghapanchi, 2008, Ghapanchi et al., 2012b, Ghapanchi et al., 2011, (Ghanbarzadeh et al., 2014, Najaftorkaman et al., 2014, Ghapanchi and Aurum, 2011). Many studies to date have been directed on effects of IT in a wide variety of fields
(Merati et al., 2012, Ghapanchi, 2013, Khosravi et al., 2012, Ghapanchi and Aurum, 2011b, Amrollahi et al., 2014, Ghapanchi et al., 2014, Ghapanchi et al., 2010, Ghapanchi et al., 2012a). Several of such studies have reported positive impact of technology on various aspects of businesses (eg. Zarei et al., 2013; Atlikhan et al., 2013; Purarjomandlangrudi et al., 2014; Talaei-Khoei et al., 2014; Vichitvanichphong et al., 2013; Ghapanchi 
et al., 2008; Ghapanchi et al., 2013; Ghapanchi, 2015). Search engine advertising is a technology which has been found as having positive impact on the businesses.

The main objective of this paper was to provide a comprehensive bibliography of prior research on search engine advertising and to structure the existing literature so as to provide guidance for the direction of future research in this domain.

We identified 101 journal publications published in the SEA domain up to February 2011. Analyzing these papers, we found that information systems (IS) was the main discipline that published SEA studies. This finding emphasized how strongly the search engine advertising phenomenon belongs to the IS discipline. Although search engine advertising is primarily a marketing strategy for promoting businesses in the online world, it should not be considered as an advertising method that solely belongs to the marketing discipline and the substantial development of SEA in the field of IS shou1d not be neglected.

There are several reasons behind the interest of the IS community in SEA. First, search engines are information systems that Internet users employ to satisfy their information needs. The infrastructure that search engine companies need for providing free search services is massive and expensive. In such a situation, sponsored search advertising is almost the only source of revenue to enable the provision of a free search service. Without sponsored search, it is unlikely that search engines could finance anything close to their infrastructure to support this free service to web users (Jansen et al., 2009a). Therefore, it is among the responsibilities of IS researchers to look into a sponsored search industry (as the most important business model for search engines that keeps the search industry alive). Second, SEA is an advertising method which is enabled by IT. Search engines supply advertisers with a system as a tool that establishes and manifests the relationship between the search engine company and advertisers. It enables advertisers to set their campaigns, decide keywords and bid amounts, monitor the progress of their ads and to analyze their marketing achievements. Third, although people tend to look at sponsored search phenomenon as an advertising model, SEA is something more than just a method of advertising. It is also a vehicle for providing relevant content to web searchers. That is why some researchers prefer to use the term 'content provider' rather than advertiser to refer to businesses using SEA (e.g. Jansen and Mullen, 2008). This provides the insight that SEA is not only a topic in advertising and marketing, but also relevant to content and information delivery to Web searchers, which is a topic in the field of IS.

Moreover, we found that there was no specific or predominant journal for publishing SEA studies and the literature in this area was spread over a wide range of journals in different disciplines. This finding is good news for SEA researchers. It implies that there is potential opportunity for publishing search engine advertising studies and that many journals are interested in publishing SEA research. So, for example, a researcher from IS field who works on factors that enable advertisers to employ SEA more effectively has the possibility of publishing their work in both IS and Marketing journals. However, this finding also indicates that when SEA research in being done, searching for related literature should not be limited to one discipline. For instance, if a researcher with marketing background works on a SEA topic, he/she has to look for literature in information systems, business, management and even mathematics and computation. Otherwise, there would be a strong possibility of that researcher overlooking good prior research.

We also classified prior SEA studies based on the research topic they investigated. We found that, in a broad sense, research on SEA can be divided into four categories: the SEA mechanism; behavioral and practical 
aspects; legality and law issues, and finally overview and review publications. The SEA mechanism and behavioral/practical related categories constitute the majority of literature on SEA - $36.6 \%$ and $50.5 \%$ respectively. We discussed that research in the first category (research on the SEA mechanism) was more concerned with the technology underlying the sponsored search industry and mostly took a mathematical and computational approach. The research had commonly been conducted by researchers with strong skill and expertise in mathematical modeling, theoretical proofing and simulation. On the other hand, research in the behavioral and practical category had been mostly been carried out by researchers that were more interested in the interaction of stakeholders (i.e., web searchers and advertises) with SEA technology and also in the actual outcomes of adopting SEA. The research in this category mostly originated from IS, marketing and management where researchers are eager to propose conceptual models and to test and validate their models using empirical data (e.g., survey questionnaire or interview).

\section{Future research direction}

We realized that even though a large number of studies exist on some of the SEA research categories and topics (e.g., SEA mechanism research or behavioral/practical research), no integrated picture of the findings is currently available. For example, several studies have been conducted to examine the attitude and perception of web searchers toward sponsored links, however the studies use different methodologies, assumptions and approaches and thus their findings are not necessarily identical or consistent. So, it is important to draw out these studies, compare and contrast them and to provide a comprehensive and holistic picture of users' perceptions of sponsored links. Therefore, we argue that there is a gap in the literature in terms of integrating and synthesizing the findings of each SEA research topic. Overcoming this shortcoming would make a substantial contribution to search engine advertising knowledge.

Moreover, we found that so far very few quantitative studies on behavioral and practical aspects of SEA from advertisers' perspective have been conducted. Except to Dinev et al. (2009), who has conducted a qualitative study based on behavioral theories to investigate the impact of click fraud on the decision of advertisers to get engaged in SEA, the research on this topic is mainly limited to exploratory qualitative studies, either based on some interviews with business managers and experts of SEA field or based on personal opinions and viewpoints of the authors of papers, without strong support by empirical evidence. Therefore, in the future there is an opportunity to expand the knowledge on advertiser-related issues by undertaking rigorous qualitative studies.

Also, a deeper look into the primary papers showed that only less than $20 \%$ of the papers have used experiment, interview, and survey questionnaire approaches, which is quite small in number. Given the fact that these approaches are fundamental in studying the behavior of individuals and organizations (Hair et al., 2007), it seems that it is essential for SEA research community to employ these methods more extensively to explore the behavior of different stake holders (e.g., web searchers and advertisers).

Lastly, through a further investigation of the primary studies, we noticed that the application and adoption of scientific theories in SEA research is very much limited. Among all 101 primary studies, only 5 have employed known theories as the foundation for their research (i.e., Dinev et al. 2009, Midha, 2009, Gauzente, 2009, 2010, and Yoo 2009). The lack of relying on theories among SEA researchers in rather surprising because a great amount of SEA literature has been developed in the fields of IS and Marketing in which theories play a substantial role in conducting academic studies. Therefore, it seems that SEA 
A Systematic Review on Search Engine Advertising / Jafarzadeh et al.

literature can be further enhanced if researchers devote more efforts into conducting interdisciplinary works by introducing theories from other fields into SEA research domain.

\section{Limitation and threads to validity}

Validity issues are one of the important concerns with any systematic review (Brereton et al., 2007). Validity is defined as "the extent to which the design and conduct of the study are likely to prevent systematic error" (Kitchenham, 2004, p.11) and stems from the bias in selecting publications and inaccuracy in extracting and synthesizing data (Kitchenham, 2004).

While we cannot fully exclude the possibility of such a bias in identifying prior SEA studies, we believe we have minimized it because: 1) based on Kitchenham's suggestions, we set a pre-defined protocol for the entire research and applied a systematic process for identifying prior publications which reduced the possibility of publication bias; 2) all the three authors were independently involved in stages 4 and 5 of the screening process (as described in selection process section), which decreased the effects of misjudgments during including/excluding phase.

Moreover, there might be a bias in extracting and synthesizing data. The classifications proposed in the study (e.g., classification on SEA research topics) are subject to the opinion of the authors. However, as all three authors have knowledge and experience in SEA research (and specially one of them is experienced in conducting and publishing systematic reviews in other fields), they have tried to make their judgments as objective as possible.

We also acknowledge that our research covers the literature till mid-2011. While as the first literature review study in the SEA domain, the finding of this research, even up to 2011, is useful to the research community, we have a plan to expand this work in the future to compare and contrast the research trend after 2011 with the earlier years.

\section{Conclusion}

In this paper, we reported the outcomes of a systematic literature review in the domain of SEA with the aim of structuring prior works in the domain and to identify directions for the future research. Relying on guidelines proposed by Kitchenham (2004), Brereton et al. (2007) and Staples and Niazi (2007), we systematically searched for and collected 101 primary journal papers published in the SEA domain before and up to February 2011. This list can serve as a comprehensive bibliography of prior research on search engine advertising.

Analyzing these prior studies, we answered five research questions, including the temporal development of SEA literature, predominant journals that publishing SEA studies, reference disciplines, main researchers of the field and also the topics of research in SEA. We found that the first SEA journal publication appeared in 2003 and since then there has been an enormous growth in SEA research. 176 authors published journal papers in this field and 24 of these authors were involved in the publication of at least two papers. The most active researcher was Bernard J. Janson who had published 12 papers and contributed to $11.8 \%$ of the literature we examined. Moreover, we found that papers in the SEA domain were distributed over a wide range of 72 journals. We also found that Information systems was the most active discipline in SEA research, followed by marketing and business. Also, we classified the primary set of SEA papers into four categories according to their research topic.

This research revealed that there is 
currently a gap in the literature in terms of integrating and synthesizing the findings of prior research in each SEA research topic. Based on this finding, we intend to expand the current study and to more thoroughly examine our set of primary sources to provide a framework which organizes the latest findings of these SEA studies. We also have a plan to review prior studies to provide a more precise and in-depth classification of research topics and to identify the research approaches used in the field of SEA. We are also interested in examining the interdependencies between research disciplines, research topics and research approaches.

\section{References}

AMROLLAHI, A., GHAPANCHI, A.H., and TALAEI-KHOEI, A. (2013). A Systematic Literature Review on Strategic Information Systems Planning: Insights from the Past Decade. Pacific Asia Journal of Association for Information Systems, Vol. 5, No. 2, pp. 39-66

AMROLLAHI, A., GHAPANCHI, A.H., and TALAEI-KHOEI, A. (2014). Three Decades of Research on Strategic Information System Plan Development, Communications of the Association for Information Systems, Vol. 34, Article 84, pp. 1439-1467

ANIMESH, A., RAMACHANDRAN, V. \& VISWANATHAN, S. 2009. Quality Uncertainty and the Performance of Online Sponsored Search Markets: An Empirical Investigation. Information Systems Research, 21, 190-201.

ARSENAULT, T. \& FEENY, D. 2008. Your Website: greater visibility and return of investment through search engine marketing DESIDOC Journal of
Library \& Information Technology 28, 79-82.

ASDEMIR, K. 2010. A dynamic model of bidding patterns in sponsored search auctions. Information Technology and Management, 12, 116.

ASHLEY, A., LARIC, M. V., LYNAGH, P. M. \& VOLLMER, C. A. 2008. A Conceptual Paradigm For Internet And Search Engine Marketing. The Journal of Applied business Research 24, 125-138.

Atlikhan, A., Albadvi, A., and Ghapanchi, A. (2013). A Conceptual Model for Proactive-Interactive Customer Complaint Management Systems, International Journal of Business Information Systems, Vol. 13, No. 4, pp. 490-503.

BARRY, C. \& CHARLETON, D. 2009. In search of search engine marketing strategy amongst SME's in Ireland. Communications in Computer and Information Science, 48, 113-124.

BLANKENBAKER, J. \& MISHRA, S. 2009. Paid search for online travel agencies: Exploring strategies for search keywords. Journal of Revenue and Pricing Management, 8, 155-165.

BRERETON, P., KITCHENHAM, B. A., BUDGEN, D., TURNER, M. \& KHALIL, M. 2007. Lessons from applying the systematic literature review process within the software engineering domain. Journal of Systems and Software, 80, 571-585.

BROOKS, N. \& MAGUN, H. 2008. Navigational behaviour and sponsored search advertising International Journal of Electronic Business, 6, 132-148. 
BU, T.-M., DENG, X. \& QI, Q. 2010. Multibidding strategy in sponsored search auctions. Journal of Combinatorial Optimization.

BU, T.-M., LIANG, L. \& QI, Q. 2009. On Robustness of Forward-looking in Sponsored Search Auction. Algorithmica, 58, 970-989.

BU, T., DENG, X. \& QI, Q. 2008. Arbitrage opportunities across sponsored search markets is. Theoretical Computer Science, 407, 182-191.

CHAITANYA, N. \& NARAHARI, Y. 2010. Optimal equilibrium bidding strategies for budget constrained bidders in sponsored search auctions. Operational Research.

CHANG, R. M., OH, W., PINSONNEAULT, A. \& KWON, D. 2010. A Network Perspective of Digital Competition in Online Advertising Industries: A Simulation-Based Approach. Information Systems Research, 21, $571-593$.

CHEN, J., FENG, J. \& WHINSTON, A. B. 2010. Keyword Auctions, Unit-Price Contracts, and the Role of Commitment. Production and Operations Management, 19, 305321.

CHEN, J., LIU, D. \& WHINSTON, A. B. 2009. Auctioning keywords in online search Journal of Marketing, 73, $125-141$.

CHEN, L.-C. 2010. Using a two-stage technique to design a keyword suggestion system Information Research 15.

CHEN, L. G. \& LI, Y. J. 2009. Allocating budget across portals in search engine advertising 2009 International Conference on

\section{Management Science and} Engineering.

CLARKE, R. 2008. Web 2.0 as syndication Journal of Theoretical and Applied Electronic Commerce Research, 3, 30-43.

CLEMONS, E. K. 2009. Business Models for Monetizing Internet Applications and Web Sites: Experience, Theory, and Predictions. Journal of Management Information Systems, 26, 15-41.

CUDMORE, B. A., MCCOY, J., SHUHY, J. \& TAYLOR, J. 2009. Engaging Online Consumers with an Interactive Cost-Per-Action Advertising Model. Journal of Internet Commerce, 8, 288-308.

DHAR, V. \& GHOSE, A. 2010. Sponsored Search and Market Efficiency. Information Systems Research, 21, 760-772.

DINEV, T., HU, Q. \& YAYLA, A. 2009. Is There an On-line Advertisers' Dilemma? A Study of Click Fraud in the Pay-Per-Click Model. International Journal of Electronic Commerce, 13, 29-59.

EDELMAN, B. 2010. Who Owns Metrics? Building a Bill of Rights for Online Advertisers. Journal of advertising research, 49, 401.

EDELMAN, B. 2011. Adverse selection in online "trust" certifications and search results. Electronic Commerce Research and Applications, 10, 1725.

EDELMAN, B. \& OSTROVSKY, M. 2007. Strategic bidder behavior in sponsored search auctions. Decision Support Systems, 43, 192-198. 
EDELMAN, B., OSTROVSKY, M. \& SCHWARZ, M. 2007. Internet Advertising and the Generalized Second-Price Auction: Selling Billions of Dollars Worth of Keywords American Economic Review, 97, 242-259.

EDELMAN, B. \& SCHWARZ, M. 2010. Optimal Auction Design and Equilibrium Selection in Sponsored Search Auctions. American Economic Review, 100, 597-602.

ELLIS, D. 1989. A behavioral approach to information retrieval system design. Journal of Documentation 45, 171211.

FENG, J., BHARGAVE, H. K. \& PENNOCK, D. M. 2007a. Implementing Sponsored Search in Web Search Engines: Conceptual Evaluation of Alternative Mechanism. INFORMS journal of computing 19, 137-148.

FENG, J., SHEN, Z.-J. M. \& ZHAN, R. L. 2007b. Ranked items auctions and online advertisement Production and Operations Management, 16, 510522.

FUXMAN, A., TSAPARAS, P., ACHAN, K. \& AGRAWAL, R. 2008. Using the Wisdom of the Crowds for Keyword Generation. International World Wide Web Conference Committee. Beijing, China.

GARG, D. \& NARAHARI, Y. 2009. An optimal mechanism for sponsored search auctions on the web and comparison with other mechanisms IEEE Transactions on Automation Science and Engineering, 6, 641-657.

GAUZENTE, C. 2009. Information search and paid results - proposition and test of a hierarchy-of-effect model. Electron Markets 19, :163-177.

GAUZENTE, C. 2010. The intention to click on sponsored ads-A study of the role of prior knowledge and of consumer profile. Journal of Retailing and Consumer Services, 17, 457-463.

GHANBARZADEH, R., GHAPANCHI, A. H., BLUMENSTEIN, M. \& TALAEIKHOEI, A. 2014. A Decade of Research on the Use of ThreeDimensional Virtual Worlds in Health Care: A Systematic Literature Review. Journal of medical Internet research, 16.

GHAPANCHI, A. H. 2013. Rallying competencies in virtual communities: A study of core processes and user interest in open source software projects. Information and Organization, 23, 129-148.

GHAPANCHI, A. H. \& AURUM, A. 2011a. Antecedents to IT personnel's intentions to leave: A systematic literature review. Journal of Systems and Software, 84, 238-249.

GHAPANCHI, A. H. \& AURUM, A. 2012. Competency rallying in electronic markets: Implications for open source project success. Electronic Markets, 22, 117-127.

GHAPANCHI, A.H., and AURUM,, A. (2011b). The Impact of Project License and Operating System on the Effectiveness of the DefectFixing Process in Open Source Software Projects, International Journal of Business Information Systems, Vol. 8, No. 4, pp. 413-424

GHAPANCHI, A.H., AURUM, A., and DANESHGAR, F. (2012a). The Impact of Process Effectiveness on 
User Interest in Contributing to the Project, Journal of software, Vol. 7, No. 1, pp. 212-219.

GHAPANCHI, A.H., WOHLIN, C., AURUM, A. (2014). Resources Contributing to Gaining Competitive Advantage for Open Source Software Projects: An Application of Resource-Based Theory, International Journal of Project Management, Vol. 32, No. 1, pp. 139-152.

GHAPANCHI, A.H., AURUM, A., and LOW, G. (2011). Creating a Measurement Taxonomy for the Success of Open Source Software Projects, First Monday, 16(8)

GHAPANCHI, A.H., TAVANA, M., KHAKBAZ, M.H., and LOW, G. (2012b). A Methodology for Selecting Portfolios of IS/IT Projects with Interactions and Under Uncertainty, International Journal of Project Management, Vol. 30, No. 7, pp. 791-803.

Ghapanchi, A.H., Jafarzadeh, M.H., and Khakbaz, M.H. (2008). Fuzzy-DEA approach to ERP system analysis and selection, International Journal of Information Systems and Change Management. Vol. 3, No. 2, pp. 157170.

Ghapanchi, A.H., Ghapanchi, A.R., TalaeiKhoei, A., Abedin, B. (2013) A Systematic Review on Information Technology Personnel's Turnover, Lecture Notes on Software Engineering, Vol. 1, No. 1, pp. 98101.

Ghapanchi, A.H. (2015). Predicting Software Future Sustainability: A Longitudinal Perspective, Information Systems, Vol. 49, pp40-51
GHOSE, A. \& YANG, S. 2008. An Empirical Analysis of Sponsored Search Performance in Search Engine Advertising. International Conference on Web Search and Data Mining.

GHOSE, A. \& YANG, S. 2009. An Empirical Analysis of Search Engine Advertising: Sponsored Search in Electronic Markets. Management Science, 55, 1605-1622.

GLASS, R. L., RAMESH, V. \& VESSEY, I. 2004. An analysis of research in computing disciplines. Communications of the ACM, 47, 89-94.

GLUHOVSKY, I. 2010. Forecasting ClickThrough Rates Based on Sponsored Search Advertiser Bids and Intermediate Variable Regression. ACM Transactions on Internet Technology, 10, 1-28.

GOEL, A., MAHDIAN, M., NAZERZADEH, H. \& SABERI, A. 2010. Advertisement allocation for generalized second-pricing schemes. Operations Research Letters, 38, 571-576.

GOLDFARB, A. \& TUCKER, C. 2008. Economic and business dimensionsSearch engine advertising. Communications of the ACM, 51, 22.

Google Quarterly Report. (2014), "Google Announces Fourth Quarter and Fiscal Year 2014 Results".

HARRIS, J. J. M., NOVALIS-MARINE, C., AMEND, R. W. \& SURPRENANT, $Z$. J. 2009. Promoting free online CME for intimate partner violence: What works at what cost?. Journal of Continuing Education in the Health 
Professions 29 (3), pp. 135-141, 29, 135-141.

HEINONEN, K. \& MICHELSSON, T. 2010. The use of digital channels to create customer relationships International Journal of Internet Marketing and Advertising, 6, 1-21.

HÖCHSTÖTTER, N. \& LEWANDOWSKI, D. 2009. What users see - Structures in search engine results pages. Information Sciences, 179, 17961812.

HOONTRAKUL, P. \& SAHADEV, S. 2004. Morethailand.com: online travel intermediary International Journal of E-Business Research 2, 94-114.

HOWARD, P. N. \& MASSANARI, A. 2007. Learning to Search and Searching to Learn: Income, Education, and Experience Online. Journal of Computer-Mediated Communication, $12,846-865$.

HUANG, H. \& KAUFFMAN, R. J. 2010. On the design of sponsored keyword advertising slot auctions: An analysis of a generalized second-price auction approach. Electronic Commerce Research and Applications.

JANSEN, B. J. 2006. Paid search. Computer, 39, 88-90.

JANSEN, B. J. 2007. The comparative effectiveness of sponsored and nonsponsored links for Web ecommerce queries. $A C M$ Transactions on the Web, 1, 3-es.

JANSEN, B. J., BROWN, A. \& RESNICK, M. 2007. Factors relating to the decision to click on a sponsored link. Decision Support Systems, 44, 4659.
JANSEN, B. J., FLAHERTY, T. B., BAEZAYATES, R., HUNTER, L., KITTS, B. \& MURPHY, J. 2009a. The Components and Impact of Sponsored Search. Computer, 42, 98-101.

JANSEN, B. J., HUDSON, K., HUNTER, L., LIU, F. \& MURPHY, J. 2008. The Google Online Marketing Challenge: Classroom Learning with Real Clients, Real Money, and Real Advertising Campaigns Journal of Interactive Advertising, 9, 75-86.

JANSEN, B. J. \& MOLINA, P. R. 2006. The effectiveness of Web search engines for retrieving relevant ecommerce links. Information Processing and Management, 42, 1075-1098.

JANSEN, B. J. \& MULLEN, T. 2008. Sponsored search: an overview of the concept, history, and technology. International Journal of Electronic Business, 6, 114 - 131.

JANSEN, B. J. \& RESNICK, M. 2006. An Examination of Searcher's Perceptions of Nonsponsored and Sponsored Links During Ecommerce Web Searching. Journal of the American Society for Information Science and Technology, 57, 19491961.

JANSEN, B. J. \& SPINK, A. 2007. Sponsored Search: Is Money a Motivator for Providing Relevant Results? Compurer 40, 52-57.

JANSEN, B. J. \& SPINK, A. 2009. Investigating customer click through behaviour with integrated sponsored and nonsponsored results. International Journal of Internet Marketing and Advertising, 5, 74-94.

JANSEN, B. J., ZHANG, M. \& SCHULTZ, C. D. 2009b. Brand and its Effect on 
A Systematic Review on Search Engine Advertising / Jafarzadeh et al.

User Perception of Search Engine Performance. Journal of the American Society for Information Science and Technology, 60, 15721595.

KARG, L. M., GROTTKE, M. \& BECKHAUS, A. 2011. A systematic literature review of software quality cost research. Journal of Systems and Software, 84, 415-427

KARJALUOTO, H. \& LEINONEN, H. 2009. Advertisers' perceptions of search engine marketing. International Journal of Internet Marketing and Advertising, 5, 95-112.

KARLIN, A. R. 2007. Ad Auctions - Current and Future Research. Lecture Notes in Computer Science, 4508 LNCS, 425.

KATONA, Z. \& SARVARY, M. 2009. The Race for Sponsored Links: Bidding Patterns for Search Advertising. Marketing Science, 29, 199-215.

KEMNITZER, K. 2010. Beyond Rescuecom v. Google: The Future of Keyword Advertising. Berkeley Technology Law Journal; 2010 Annual Review, $25,401-427$.

KENNEDY, K. \& KENNEDY, B. B. 2008. A small company's dilemma: using search engines effectively for corporate sales. Management Research News, 31, 737-745.

KIM, N. Y. \& SUNDAR, S. 2010. Relevance to the rescue: Can "smart ads" reduce negative response to online ad clutter?. Journalism and Mass Communication Quarterly, 87, 346362.

KITCHENHAM, B. A. 2004. Procedures for Undertaking Systematic Reviews. Joint Technical Report. Computer
Science Department, Keele University (TR/SE-0401) and National ICT Australia Ltd (0400011T.1).

KITTS, B. \& LEBLANC, B. 2004. Optimal Bidding on Keyword Auctions. Electronic Markets, 14, 186-201.

KSHETRI, N. 2010. The economics of click fraud IEEE Security and Privacy, 8, 45-53.

LAFFEY, D. 2007. Paid search: The innovation that changed the Web. Business Horizons, 50, 211-218.

LAFFEY, D., HUNKA, C., SHARP, J. \& ZENG, Z. 2009. Estimating advertisers' values for paid search clickthroughs. Journal of the Operational Research Society, 60, 411-418.

LAFFEY, D. \& SHARP, J. 2008 Teaching Case: Paid Search Wars Communications of AIS, 22, 589602.

LEE, C. B. P. 2010. Online Help for Problem Gambling Among Chinese Youths. International Journal of Mental Health and Addiction.

LEHRKE, C. \& RIEMER, K. 2009. Biased Listing in Electronic Marketplaces: Exploring Its Implications in On-Line Hotel Distribution. International Journal of Electronic Commerce, 14, 55-78.

LI, J. 2010. Selection of Best Keywords: A Poisson Regression Model. Journal of Interactive Advertising, 11, 27-35.

LINDHEIMER, D., LEW, S. \& WONG, C. 2009. Innovation: The China Style. Proceedings of the IEEE, 97, 1551 1554 
LIU, D. \& CHEN, J. 2006. Designing online auctions with past performance information. Decision Support Systems, 42, 1307-1320.

LIU, D., CHEN, J. \& WHINSTON, A. B. 2009. Ex Ante Information and the Design of Keyword Auctions. Information Systems Research, 21, 133-153.

MA, Z., LIAO, K. \& LEE, J. J.-Y. 2010a. Examining Comparative Shopping Agents from Two Types of Search Results. Information Systems Management, 27, 3-9.

MA, Z., PANT, G. \& SHENG, O. R. L. $2010 \mathrm{~b}$. Examining organic and sponsored search results: A vendor reliability perspective Journal of Computer Information Systems, 50, 30-38.

MALKAWI, B. H. 2010. Google's use of Rescuecom's trademark as an advertising keyword and the U.S. Federal Trademarks Act. Computer Law \& Security Review, 26, 77-89.

MANDELLI, A. 2005. Banners, e-mail, advertainment and sponsored search: proposing a value perspective for online advertising. International Journal of Internet Marketing and Advertising, 2, 92-108

MCANULTY, J. D. 2009. Bringing patient recruitment into our digital world Drug Information Journal, 43, 501508.

MEHTA, A., SABERI, A., VAZIRANI, U. \& VAZIRANI, V. 2007. AdWords and generalized online matching. Journal of the ACM, 54, 22-es.

MERATI, E., ZAREI, B., and GHAPANCHI, A. (2010). Project Process Reengineering (PPR): A BPR Method for Projects, International Journal of
Information Systems and Change Management. Vol. 4, No.4 pp. 299 313.

MIDHA, V. 2009. The Glitch in On-line Advertising: A Study of Click Fraud in Pay-Per-Click Advertising Programs. International Journal of Electronic Commerce,13, 91-111.

MILGROM, P. 2010. Simplified mechanisms with an application to sponsoredsearch auctions ir. Games and Economic Behavior, 70, 62-70.

MOROCHOVE, R. 2008. Search engine optimization, advertising $101 P C$ World (San Francisco, CA), 26, 4748.

MORRIS, C. A. \& AVORN, J. 2003. Internet Marketing of Herbal Products Journal of the American Medical Association, 290, 1505-1509.

MOWSHOWITZ, A. \& KUMAR, N. 2009. And Then There Were Three Computer, 42, 108 -107

MURPHY, H. C. 2008. Do small and medium-sized hotels exploit search engine marketing? International Journal of Contemporary Hospitality Management, 20, 90-97.

NAJAFTORKAMAN, M., GHAPANCHI, A. H., TALAEI-KHOEI, A. \& RAY, P. 2014. A taxonomy of antecedents to user adoption of health information systems: A synthesis of thirty years of research. Journal of the Association for Information Science and Technology.

NALDI, M., D'ACQUISTO, G. \& ITALIANO, G. F. 2010. The value of location in keyword auctions. Electronic Commerce Research and Applications, 9, 160-170. 
NEUMAN, W. L. 2006. Social Research Methods: Qualitative and Quantitative Approaches, Boston, Allyn and Bacon.

NICHOLSON, S., SIERRA, T., ESERYEL, U. Y., PARK, J.-H., BARKOW, P., POZO, E. J. \& WARD, J. 2006. How much of it is real? Analysis of paid placement in web search engine results JOURNAL OF THE AMERICAN SOCIETY FOR INFORMATION SCIENCE AND TECHNOLOGY, 57, 448-461.

O'CONNOR, P. 2009. Pay-per-click search engine advertising: Are hotel trademarks being abused? . Cornell Hospitality Quarterly, 50, 232-244.

OHLY, A. 2010. Keyword advertising or why the ECJ's functional approach to trade mark infringement does not function IIC International Review of Intellectual Property and Competition Law, 41, 879-881.

ÖZLÜK, Ö. \& CHOLETTE, S. 2007. Allocating expenditures across keywords in search advertising. Journal of Revenue and Pricing Management, 6, 347-356.

PETTER, S., DELONE, W. \& MCLEAN, E. 2008. Measuring information systems success: models, dimensions, measures, and interrelationships. European Journal of Information Systems, 17, 236-263.

POLANSKI, P. P. 2011. Technical, automatic and passive: Liability of search engines for hosting infringing content in the light of the Google ruling Journal of International Commercial Law and Technology, 6, 42-50.

PORTER, A. 2007. Target practice in search engine marketing, opportunity outweighs risk Marketing Health Services, 27, 26-28.

Purarjomandlangrudi, A., Ghapanchi, A.H., Esmalifalak, A. (2014). A Data Mining Approach for Fault Diagnosis: An Application of Anomaly Detection Algorithm, Measurement, Vol. 55, pp. 343-352

Quinn P., Gamache M., Paroz S. (2012), "Sponsored search advertising: How statistical and optimization methods help advertisers manage their Internet campaigns more efficiently", Analytics, May/June issue, pp. 26-31

RASHTCHY, S., KESSLER, A. M., BIEBER, P. J., SCHINDLER, N. H. \& TZENG, J. C. 2007. The user revolution: the new advertising ecosystem and the rise of the internet as a mass medium. Piper Jaffray.

ROSSO, M. A. \& JANSEN, B. J. 2010. Brand names as keywords in sponsored search advertising Communications of the Association for Information Systems, 27, 81-98.

RUTZ, O. J. \& BUCLIN, R. E. 2011. From Generic to Branded: A Model of Spillover in Paid Search Advertising Journal of Marketing Research, 48, 87-102.

SEN, R. 2005. Optimal Search Engine Marketing Strategy. International Journal of Electronic Commerce, 10, 9-25.

SHEN, Z.-J. M. \& SU, X. 2007. Customer Behavior Modeling in Revenue Management and Auctions: A Review and New Research Opportunities Production \& Operations Management, 16, 713728. 
SHOEMAKER, G. R. 2009. Don't blame Google: Allowing trademark infringement actions against competitors who purchase sponsored links on internet search engines under the initial interest confusion doctrine Catholic University Law Review, 58, 535-566.

SKIERA, B., ECKERT, J. \& HINZ, O. 2010. An analysis of the importance of the long tail in search engine marketing. Electronic Commerce Research and Applications, 9, 488-494.

SPINK, A., JANSEN, B. J., KATHURIA, V. \& KOSHMAN, S. 2006. Overlap among major web search engines. Internet Research, 16, 419-426.

STAPLES, M. \& NIAZI, M. 2007. Experiences using systematic review guidelines. Journal of Systems and Software, 80, 1425-1437

Talaei-Khoei, A., Vichitvanichphong, S., Solvoll, T., Ray, P., and Ghapanchi, A.H. (2014). A Methodology to Develop Awareness in Agents using Policies, Journal of Computer and System Sciences, Vol. 80, pp, 13231338

TAY, P. S. 2009. Keyword Advertising: Challenging the Traditional Concept of "Use" under Malaysian Trade Mark Law. Asian Journal of Comparative Law, 4.

TOMAK, K. \& MAHDIAN, M. 2008. Pay-PerAction Model for On-line Advertising. International Journal of Electronic Commerce, 13, 113-128.

TURNBULL, D. \& BRIGHT, L. F. 2008. Advertising academia with sponsored search: an exploratory study examining the effectiveness of Google AdWords at the local and global level. International journal of Electronic Business, 6, 149-171.

TYACKE, N. \& HIGGINS, R. 2004. Searching for trouble-keyword advertising and trade mark infringement Computer Law and Security Report 20, 453-465

Vichitvanichphong, S., Talaei-Khoei, A., Kerr, D., and Ghapanchi, A.H. (2013) Analysis of Research in Adoption of Assistive Technologies for Aged Care, Australasian Conference on Information Systems (ACIS), Melbourne, Australia

WALJI, M., SAGARAM, S., MERICBERNSTAM, F., JOHNSON, C. W. \& BERNSTAM, E. V. 2005. Searching for cancer-related information online: Unintended retrieval of complementary and alternative medicine information. International Journal of Medical Informatics, 74, 685-693.

WEBER, T. A. \& ZHENG, Z. 2007. A Model of Search Intermediaries and Paid Referrals. Information Systems Research, 18, 414-436.

YAHYA, M. A., YURTSEVEN, Ö. \& ASDEMIR, K. 2008. An Economic Model of Click Fraud in Publisher Networks. International Journal of Electronic Commerce, 13, 61-90.

YANG, S. \& GHOSE, A. 2010. Analyzing the Relationship Between Organic and Sponsored Search Advertising: Positive, Negative, or Zero Interdependence? Marketing Science, 29, 602-623.

YOON, K. 2010. Optimal quality scores in sponsored search auctions: Full extraction of advertisers' surplus B.E. Journal of Theoretical Economics, 10, no. 28. 
ZAREI, B. \& GHAPANCHI, A. 2008. Guidelines for government-togovernment initiative architecture in developing countries. International Journal of Information Management, $28,277-284$.

Zarei, B., Azizian, S., and Ghapanchi, A. (2013). Road freight information systems: a soft system methodology approach, International Journal of Logistics Systems and Management, Vol. 14, No. 2, pp. 161-178.

ZENG, D., WANG, F.-Y., ZHENG, X., YUAN, Y., CHEN, G. \& CHEN, J. 2008. Intelligent-commerce research in China IEEE Intelligent Systems, 23, 14-18.

ZHANG, Y., JANSEN, B. J. \& SPINK, A. 2009. Time series analysis of a Web search engine transaction log. Information Processing and Management, 45, 230-245.

ZWEIHORN, Z. J. 2006. Searching for confusion: The initial interest confusion doctrine and its misapplication to search engine sponsored links Cornell Law Review, $91,1343-1381$.

\section{Appendix A: Journals with one SEA publication}

ACM Transactions on Internet Technology, ACM Transactions on the Web, Algorithmica, Asian Journal of Comparative Law, B.E. Journal of Theoretical Economics, Berkeley Technology Law Journal, Business Horizons, Catholic University Law Review, Communications of AIS, Communications of the ACM, Communications of the
Association for Information Systems, Cornell Hospitality Quarterly, Cornell Law Review, DESIDOC Journal of Library \& Information Technology, Drug Information Journal, Games and Economic Behavior, IEEE Intelligent Systems, IEEE Security and Privacy, IEEE Transactions on Automation Science and Engineering, IIC International Review of Intellectual Property and Competition Law, Information Research, Information Sciences, Information Systems Management, Information Technology and Management, INFORMS Journal on Computing, International Journal of Contemporary Hospitality Management, International Journal of E-Business Research, International Journal of Medical Informatics, International Journal of Mental Health and Addiction, Internet Research, Journal of Advertising Research, Journal of Applied Business Research, Journal of Combinatorial Optimization, Journal of Computer Information Systems, Journal of Computer-Mediated Communication, Journal of Continuing Education in the Health Professions, Journal of International Commercial Law and Technology, Journal of Internet Commerce, Journal of Management Information Systems, Journal of Marketing, Journal of Marketing Research, Journal of Retailing and Consumer Services, Journal of Revenue \& Pricing Management, Journal of Revenue and Pricing Management, Journal of the ACM, Journal of the American Medical Association, Journal of the Operational Research Society, Journal of Theoretical and Applied Electronic Commerce Research, Journalism and Mass Communication Quarterly, Management Research News, Management Science, Marketing Health Services, Operational Research: An International Journal, Operations Research Letters, Proceedings of the IEEE, Production \& Operations Management, Theoretical Computer Science, 


\section{Appendix B: Classification of primary studies based on research topic}

Research about SEA mechanism: Asdemir (2010), Bu et al. (2008), Bu et al. (2009), Bu et al. (2010), Chaitanya and Narahari (2010), Chang et al. (2010), Chen (2010), Chen et al. (2009), Chen et al. (2010), Cudmore et al. (2009), Dhar and Ghose (2010), Edelman and Ostrovsky (2007) Edelman and Schwarz (2010), Edelman et al. (2007), Feng et al. (2007a), Feng et al. (2007b), Garg and Narahari (2009a), Gluhovsky (2010), Goel et al. (2010), Huang and Kauffman (2010), Katona and Sarvary (2009), Kitts and Leblanc (2004), Laffey et al. (2009), Liu and Chen (2006), Liu et al. (2009), Mandelli (2005), Mehta et al. (2007), Milgrom (2010), Naldi et al. (2010), Özlük and Cholette (2007), Rosso and Jansen (2010), Rutz and Buclin (2011), Skiera et al. (2010), Tomak and Mahdian (2008), Weber and Zheng (2007), Yahya et al. (2008), Yoon (2010)

Behavioral and practical research: Animesh et al. (2009), Arsenault and Feeny (2008), Blankenbaker and Mishra (2009), Brooks and Magun (2008), Clarke (2008), Clemons (2009), Dinev et al. (2009), Edelman (2010), Edelman (2011), Gauzente (2009), Gauzente (2010), Ghose and Yang (2009), Goldfarb and Tucker (2008), Harris et al. (2009), Heinonen and Michelsson (2010), Höchstötter and Lewandowski (2009), Hoontrakul and Sahadev (2004), Howard and Massanari (2007), Jansen (2007), Jansen and Molina (2006), Jansen and Resnick (2006), Jansen and Spink (2009), Jansen et al. (2007), Jansen et al. (2008), Jansen et al. (2009b), Karjaluoto and Leinonen (2009), Kennedy and Kennedy (2008), Kim and Sundar (2010), Kshetri (2010), Laffey (2007), Lee (2010), Lehrke and Riemer (2009), Li (2010), Lindheimer et al. (2009), Ma et al. (2010a), Ma et al. (2010b), McAnulty (2009), Midha (2009), Morris and Avorn (2003) Mowshowitz and Kumar (2009), Murphy (2008), Nicholson et al. (2006), O'Connor
(2009), Porter (2007), Sen (2005), Shen and Su (2007), Spink et al. (2006), Turnbull and Bright (2008), Walji et al. (2005), Yang and Ghose (2010), Zhang et al. (2009)

Law-related research: Kemnitzer (2010), Malkawi (2010), Ohly (2010), Polanski (2011), Shoemaker (2009), Tay (2009), Tyacke and Higgins (2004), Zweihorn (2006)

Overview/review research: Ashley et al. (2008), Jansen (2006), Jansen and Mullen (2008), Laffey and Sharp (2008), Zeng et al. (2008)

\section{About The Authors}

Hamed Jafarzadeh received his $\mathrm{PhD}$ from the School of Information Systems, Technology and Management, University of New South Wales, Australia. He holds a $\mathrm{BSc}$ in industrial engineering and an MSc in IT management. He currently works at University of Queensland in the position of specialist business analyst and IT project manager. His main research interests include social networking technologies, search engine advertising, IT strategy alignment, enterprise resource planning implementation, and business systems analysis.

Aybüke Aurum is the executive director of Aurum Academia, a software consulting company in Sydney, Australia. She has previously worked as an associate professor of Information Systems in the School of Information Systems, Technology and Management, University of New South Wales (1998-2014), and on the Faculty of Information Sciences and Engineering, University of Canberra (1997-1998). Dr. Aurum received her $\mathrm{BSc}$ and $\mathrm{MSc}$ in geological engineering at Istanbul Technical University and MEngSc and PhD degrees in computer science from the University of New South Wales. Her research interests include requirements engineering, agile development, outsourcing, and global software development. Dr. Aurum has produced over 130 publications, including three edited books, namely Managing 
A Systematic Review on Search Engine Advertising / Jafarzadeh et al.

Software Engineering Knowledge, Engineering and Managing Software Requirements, and Value-Based Software Engineering published by Springer. Dr. Aurum is on the editorial board of Information and Software Technology published by Elsevier, and Requirements Engineering published by Springer. She is a member of IEEE, the Association for Information Systems, and the Australian Computer Society.

John D'Ambra holds a doctorate in Information Systems from the University of New South Wales, where he is currently an associate professor. His research interests include evaluating ubiquitous computing, mobile-health, user perceptions of the value of the World Wide Web, communication behavior, and e-learning. Dr. D'Ambra has published extensively in such leading international journals as the Journal of the American Society for Information Science and Technology, Journal of Knowledge Management, Information and Management, Journal of Communication, and Electronic Markets. He received the 2009 Rudolph J. Joenk, Jr. Award for Best Paper in the IEEE Transactions on Professional Communication. Prior to entering academia
Dr. D'Ambra's experience in the commercial IT industry included positions at Pacific Power and the Australian Broadcasting Corporation.

Amir Ghapanchi is a senior lecturer at the School of Information and Communication Technology, Griffith University, Australia. Amir has published over 80 referred publications including 46 journal articles in prestigious information systems and management journals such as tier $A^{*} / A$ journals of Information and Organization, Communications of the Association for Information systems, International Journal of Medical Informatics, Journal of Medical Internet Research, Journal of the Association for Information Science and Technology (JASIST), Journal of Organizational Computing and Electronic Commerce, Electronic Markets, Journal of Computer and System Sciences, International Journal of Project Management, Journal of Systems and Software, Australasian Journal of Information systems and International Journal of Information Management. Dr Ghapanchi has also published in the prestigious IS conferences including ICIS, AMCIS, PACIS and ACIS. 